EXTENDED REPORT

\title{
Cytokine and chemokine receptor profile of peripheral blood mononuclear cells during treatment with infliximab in patients with active rheumatoid arthritis
}

\author{
R Nissinen, M Leirisalo-Repo, R Peltomaa, T Palosuo, O Vaarala
}

Ann Rheum Dis 2004;63:681-687. doi: 10.1136/ard.2003.008599

See end of article for authors' affiliations .....................

Correspondence to: Dr R Nissinen, National Public Health Institute, Department of Molecular Medicine, Biomedicum, PO Box 104, 00251 Helsinki, Finland; riikka.nissinen@ktl.fi

Accepted 14 June 2003

\begin{abstract}
Objectives: To analyse immunological changes during treatment with a monoclonal anti-tumour necrosis factor $\alpha$ (TNF $\alpha$ ) antibody, infliximab, in patients with rheumatoid arthritis (RA).

Methods: 25 patients with RA and 5 patients with other arthritides were studied during the first 6 weeks of treatment with infliximab. At the start of treatment and after 2 and 6 weeks, spontaneous expression of CCR3 and CCR5 on peripheral blood T cells and monocytes was studied by flow cytometry. The secretion and mRNA expression of interferon $\gamma$ (IFN $\gamma$ ), interleukin (IL)4, IL5, and TNF $\alpha$ from phytohaemagglutinin (PHA) stimulated peripheral blood mononuclear cells was measured with an ELISA and RT-PCR. Plasma levels of $C$ reactive protein, serum amyloid protein $A$, rheumatoid factor, and antibodies to filaggrin and citrullinated cyclic peptide were measured with an ELISA.

Results: The number of CD4 T cells and CD14 monocytes expressing CCR3 ( $p=0.013, p=0.009$, respectively) and CD8 T cells expressing CCR5 $(p=0.040)$ as well as PHA stimulated secretion of IL4 and IFN $\gamma(p<0.05)$ increased during treatment in patients with RA. $15(60 \%)$ patients with RA achieved clinical response (at least ACR20) during the first 2 weeks. The number of T cells expressing CCR3 and CCR5 was higher before treatment in non-responders than in responders $(p<0.05)$. The number of $\mathrm{T}$ cells increased in responders.

Conclusion: Increase in secretion of Th1 and Th2 cytokines together with induced expression of chemokine receptors on T cells and monocytes suggest restoration of peripheral cell mediated immunity and blockade of the accumulation of inflammatory cells in joints as response to treatment.
\end{abstract}

$\mathrm{T}$ he inflamed synovium of patients with rheumatoid arthritis (RA) is characterised by massive leucocytic infiltration, mainly consisting of macrophages, T lymphocytes, and plasma cells. These cells express many proinflammatory cytokines, chemokines, and growth factors and are considered responsible for the degradation of the cartilage and erosion of juxta-articular bone. ${ }^{12}$

Tumour necrosis factor $\alpha(\mathrm{TNF} \alpha)$ is expressed mainly by cells of the macrophage/monocyte lineage and is the most abundant and rapidly produced ${ }^{3}$ proinflammatory cytokine in the rheumatoid joint. It has a central role in regulation of the synthesis and function of proinflammatory molecules and is involved in the recruitment of immune cells infiltrating into the joints. ${ }^{4}$

Treatment with agents blocking the function of TNF $\alpha$ has proved to be highly effective in RA. To date there are two blocking agents in clinical use, a soluble TNF $\alpha$ receptor, etanercept, and a monoclonal antibody, infliximab. ${ }^{56}$

The mechanisms behind the clinical effect of TNF $\alpha$ blocking treatment are not fully understood. TNF $\alpha$ blocking by antibodies or soluble receptors reduces the expression of vascular adhesion molecules ${ }^{7}$ and inhibits the spontaneous production of interleukin (IL) 1 and IL6 in an animal model. ${ }^{8}$ Within days after starting infliximab treatment serum IL6 levels fall to normal and $C$ reactive protein (CRP), primarily controlled by IL6, normalises. ${ }^{9}{ }^{10}$ In patients with RA also an increase in the production of interferon $\gamma$ (IFN $\gamma)$ by lymphocytes has been reported after treatment with soluble TNF $\alpha$ receptor. ${ }^{11}$ At the same time, reduction in the homing of lymphocytes to the joints is seen.

$\mathrm{TNF} \alpha$ also participates in the formation of new blood vessels in the rheumatoid joint. This not only enables enhanced delivery of inflammatory cells and mediators to the joint but also creates an invasive property of pannus at the cartilage and bone junction. Blocking of TNF $\alpha$ reduces the raised concentrations of serum vascular endothelial growth factor ${ }^{12}$ detected in patients with RA and reduces angiogenesis. However, the immediate immunological mechanisms resulting from the blocking of $\mathrm{TNF} \alpha$ are crucial because clinical improvement is seen in days after the start of treatment.

To study the mechanisms in the TNF $\alpha$ blockade we examined the expression of chemokine receptors (CCR3, CCR5), and the secretion of IL4, IL5, IFN $\gamma$, and TNF $\alpha$ in peripheral blood T cells and monocytes of patients with active RA or other arthritides during early treatment with infliximab. The mRNA expression of IFN $\gamma$, IL4, IL5, and TNF $\alpha$ in peripheral blood mononuclear cells (PBMC) was assessed with real time reverse transcriptase-polymerase chain reaction (RT-PCR). We also followed the changes in plasma levels of acute phase reactants, such as CRP, serum amyloid protein A (SAA), rheumatoid factor (RF), antifilaggrin antibodies (AFA), and antibodies to filaggrin derived cyclic citrullinated peptide $(\mathrm{aCCP})$.

\footnotetext{
Abbreviations: ACR, American College of Rheumatology; AFA, antifilaggrin antibodies; BSA, bovine serum albumin; CCP, cyclic citrullinated peptide; CRP, $C$ reactive protein; DMARD, disease modifying antirheumatic drug; ELISA, enzyme linked immunosorbent assay; FACS, fluorescence activated cell sorter; IFN $\gamma$, interferon $\gamma$; IL, interleukin; PBMC, peripheral blood mononuclear cells; PBS, phosphate buffered saline; PHA, phytohaemagglutinin; RA, rheumatoid arthritis; RF, rheumatoid factor; RT-PCR, reverse transcriptase-polymerase chain reaction; SAA, serum amyloid $A ; T$, Tween; TNF $\alpha$, tumour necrosis factor $\alpha$
} 


\section{PATIENTS AND METHODS \\ Patients}

We studied 25 patients with active RA who had not responded to conventional treatment with disease modifying antirheumatic drugs (DMARDs), including methotrexate, and five patients with other chronic active joint diseases (two patients with psoriatic arthritis, one with chronic reactive arthritis, one with spondyloarthropathy, and one with juvenile idiopathic arthritis) in whom treatment with infliximab was started. At the time of examination, all patients were using varying antirheumatic drugs either as a single DMARD or in different combinations. Twenty one patients with RA and four patients with other arthritides were receiving low dose $(<10 \mathrm{mg} /$ day $)$ prednisone. Table 1 presents the characteristics of the patients.

In the patients with RA the response to infliximab was evaluated at week 2 by calculating the American College of Rheumatology (ACR) response ${ }^{13}$ (in two patients the information was available only at week 6). Patients with an improvement of at least $20 \%$ (ACR20) were considered to be responders. Fifteen patients with RA were considered to be responders, 10 non-responders.

Nine healthy people matched for age and sex were studied as controls.

\section{Cell extraction}

EDTA-blood was collected from the patients immediately before the infusions of infliximab $(3 \mathrm{mg} / \mathrm{kg})$ at the start and at 2 and 6 weeks during the treatment. EDTA-blood was taken at 2 week intervals from healthy controls.

PBMC were isolated by Ficoll gradient centrifugation. The cells were then washed three times with pyrogen free phosphate buffered saline (PBS) and suspended in a concentration of $2 \times 10^{6}$ cells $/ \mathrm{ml}$ in RPMI medium containing $5 \% \mathrm{AB}$ serum, $25 \mathrm{mM}$ Hepes, $2 \mathrm{mM}$ glutamine, and $25 \mu \mathrm{g} / \mathrm{ml}$ gentamicin.

\section{Fluorescence activated cell sorter (FACS) for chemokine receptor analysis}

PerCP conjugated antihuman CD3, FITC conjugated antihuman CD8 and CD14, and PE conjugated antihuman IFN $\gamma$ and IL4 antibodies and isotype control and leucogate were purchased from Becton Dickinson (BD, Erembodegem, Belgium). PE conjugated antihuman CCR3 and CCR5 antibodies were purchased from R\&D (Abingdon, UK).

Ex vivo PB derived cells were washed with PBS containing $0.5 \%$ bovine serum albumin (PBS-BSA) and resuspended in $1 \mathrm{ml}$ of PBS-BSA. To detect CD3, CD8, CD14, CCR3, and CCR5, $2 \times 10^{5}$ cells were incubated for 20 minutes in the dark with $5 \mu \mathrm{l}$ of each labelled monoclonal antibody. The cells were then washed once with PBS-BSA and suspended in FACS Flow solution for analysis.

Stained cells (20000) were gated by side scatter and fluorochrome parameters for the $\mathrm{T}$ cell (CD3 perCP) and monocyte (CD14 FITC) analyses (FACS Calibur, BD). CD3 gated CD8 negative T cells were considered as CD4 cells.

The results were expressed as the percentage of cells staining positive for different markers. The cut off point for positive staining for intracellular cytokines and chemokine receptors is above the level of the control isotype antibody.

\section{Cell stimulation}

Ficoll isolated cells were stimulated in a concentration of $2 \times 10^{5}$ cells in $200 \mu \mathrm{l}$ volume with $5 \mu \mathrm{g} / \mathrm{ml}$ phytohaemagglutinin (PHA) for 24 hours in $\mathrm{U}$ bottomed plates at $37^{\circ} \mathrm{C}$. Supernatants and cells were collected 24 hours after the stimulation and analysed further.

\section{Enzyme linked immunosorbent assay (ELISA) for IFN $\gamma$, IL5, IL4, and TNF $\alpha$}

For detection of IFN $\gamma, 96$ well microtitre plates (Maxisorb, Nunc, Roskilde, Denmark) were coated with monoclonal antihuman IFN $\gamma$ antibody (clone 2Gl; Endogen, Woburn, MA) at a concentration of $2 \mu \mathrm{g} / \mathrm{ml}(50 \mu \mathrm{l} /$ well $)$ and incubated overnight at $4^{\circ} \mathrm{C}$. After washing with PBS containing $0.05 \%$ Tween (PBS-T), the plates were blocked with $1 \%$ BSA in PBS for 30 minutes. Dilutions of recombinant human IFN $\gamma$ (catalogue No 19751N; Pharmingen, San Diego, CA) were used to create a standard curve. Supernatant samples and standards were incubated for 2 hours. After washing with PBS-T, biotinylated antihuman IFN $\gamma$ monoclonal antibody (clone B133.5; Endogen) was added at a concentration of $0.5 \mu \mathrm{g} / \mathrm{ml}(50 \mu \mathrm{l} /$ well $)$ and the plates were incubated for 1.5 hours. After washing with PBS-T, streptavidin-alkaline phosphatase complex (Zymed, San Francisco, CA) was added for 30 minutes' incubation. $p$-Nitrophenyl phosphate (Medix, Kauniainen, Finland) was used to develop the colour for reading at $405 \mathrm{~nm}$. The concentration of IFN $\gamma$ secreted into the supernatants of unstimulated cells was subtracted from that of the stimulated cells. The detection level of the assay was $50 \mathrm{pg} / \mathrm{ml}$.

Measurement of IL5 was performed according to the protocol used for IFN $\gamma$. Purified rat antihuman IL5 (1 $\mu \mathrm{g} / \mathrm{ml}$; clone TRFK5, Pharmingen) was used as primary antibody and biotinylated rat antihuman IL5 $(0.5 \mu \mathrm{g} / \mathrm{ml}$; clone JESI5Al0, Pharmingen) as secondary antibody. Dilutions of recombinant human IL5 (catalogue No 1965lV, Pharmingen) were used to create the standard curve. The detection level for IL5 was $30 \mathrm{pg} / \mathrm{ml}$.

IL4 was measured from the supernatants by PeliKine Compact human IL4 ELISA kit (catalogue No M1914; CLB,

\begin{tabular}{|c|c|c|}
\hline Demographics & $\begin{array}{l}\text { Rheumatoid arthritis } \\
(n=25)\end{array}$ & $\begin{array}{l}\text { Arthritis controls } \\
(\mathrm{n}=5)\end{array}$ \\
\hline Age (years), mean (range) & $55(34-76)$ & $38(22-56)$ \\
\hline Sex (female/male) & $19 / 6$ & $0 / 5$ \\
\hline Disease duration (years), mean (range) & $13(3-32)$ & $9.4(1-16)$ \\
\hline RF (No positive) & 20 & 1 \\
\hline Swollen joint count, mean (range) & $17(6-38)$ & $11(0-30)$ \\
\hline Tender joint count, mean (range) & $21(2-41)$ & $11(1-24)$ \\
\hline Patient's global assessment (mm), mean (range) & $7.3(2.5-10.2)$ & $7(5.6-9)$ \\
\hline Physician's global assessment (mm), mean (range) & $6.8(3.8-10.2)$ & $6.7(4.6-9)$ \\
\hline $\operatorname{ESR}(\mathrm{mm} / 1 \mathrm{st} \mathrm{h})$, mean (range) & $50(10-108)$ & $70(16-104)$ \\
\hline $\mathrm{C}$ reactive protein $(\mathrm{mg} / \mathrm{l})$, mean $(\mathrm{range})^{*}$ & $83(5-272)$ & $28.5(6.7-92)$ \\
\hline S-amyloid protein $\mathrm{A}(\mathrm{mg} / \mathrm{l})$, mean (range)† & $226(14.5-495)$ & $199(20-303)$ \\
\hline
\end{tabular}


Amsterdam, Netherlands) and TNF $\alpha$ by human TNF $\alpha$ ELISA kit (catalogue No 1425 943; Roche Diagnostics, Mannheim, Germany), according to the instructions of the manufacturer. The concentration of cytokine secreted into the supernatants of unstimulated cells was subtracted from that of the stimulated cells. The detection level of the kit for IL4 was $2 \mathrm{pg} / \mathrm{ml}$ and for $\mathrm{TNF} \alpha 20 \mathrm{pg} / \mathrm{ml}$.

\section{ELISA for CRP, SAA, and IgM RF}

CRP, SAA, and IgM RF were detected in plasma according to the manufacturer's protocol with CRP EIA kit (Eucardio Laboratory, Inc, San Diego, CA, USA), Cytoscreen human SAA (Biosource International, Camarillo, CA, USA), and QuantaLite RF IgM ELISA (INOVA Diagnostics, Inc, San Diego, CA, USA), respectively.

\section{ELISA for antifilaggrin antibodies}

The extraction and purification of filaggrin from human skin was effected and used as an antigen in an ELISA as previously described. ${ }^{14}$

\section{ELISA for aCCP}

Cyclic citrullinated peptide (CCP; $\mathrm{cfcl}-\mathrm{-yc})$, described by Schellekens et $a l,{ }^{15}$ was used as the antigen. The peptide was synthesised, cyclicised, and purified by high performance liquid chromatography at the Institute of Biotechnology, University of Helsinki (Dr C Kantor-Aaltonen).

CCP at a concentration of $1 \mu \mathrm{g} / \mathrm{ml}$ in $50 \mathrm{mM}$ ammonium bicarbonate buffer, pH 9.6, was applied onto 96 well microtitre plates ( $100 \mu \mathrm{l} /$ well; EXICON, Peptide immobiliser). The plates were incubated overnight at $4^{\circ} \mathrm{C}$. The wells were then emptied and washed three times with PBS-T. Human serum samples $(100 \mu \mathrm{l})$, diluted $1: 200$ in PBS-T containing $0.2 \%$ human serum albumin (Finnish Red Cross Blood Transfusion Service, Helsinki, Finland), were then applied onto the plates and incubated at room temperature for 1.5 hours. After the incubation the wells were rinsed three times with PBS-T, and $100 \mu \mathrm{l}$ of alkaline phosphatase conjugated rabbit antihuman IgG (Jackson Immunoresearch, West Grove Pa, USA) diluted 1:1000 in PBS-T was added and incubated for 1 hour at room temperature. After rinsing the wells three times with PBS-T, the substrate ( $p$-nitrophenyl phosphate; Sigma, St Louis, Mo, USA), l mg/ $\mathrm{ml}$ in $50 \mathrm{mM}$ carbonate buffer, $\mathrm{pH} 9.8$, was added. The developed colour was read at $405 \mathrm{~nm}$ with an automated ELISA reader (Titertek Multiskan; Eflab, Helsinki, Finland) when a predetermined optical density level of reference RA sera was reached. The mean intra-assay variation of the method for a high positive serum was $6.4 \%$, and for a low positive serum $5.9 \%$ (20 determinations). Interassay variation was $6 \%$ for a high positive serum and $14 \%$ for a low positive serum in seven successive tests.

\section{Real time reverse transcriptase-polymerase chain reaction ( $R T-P C R$ )}

The mRNA expression of cytokines and chemokine receptors was detected by real time RT-PCR from unstimulated and PHA stimulated cells.

Total RNA (tRNA) was extracted from frozen cells stored at $-70^{\circ} \mathrm{C}$ in the lysis buffer of RNA Total Gen Elute Mammalian RNA kit. The reverse transcription reaction was carried out in a final volume of $20 \mu \mathrm{l}$ by using TaqMan Reverse Transcription Reagents (Applied Biosystems, Foster City, CA, USA). The solution was treated with $0.01 \mathrm{U} / \mu$ l DNAase (Boehringer Mannheim) before adding the Multiscribe Reverse Transcriptase-enzyme (1.25 U/ $\mu \mathrm{l})$.

Real Time PCR was performed using an automated fluorometer, ABI Prism 7700 Sequence Detection System (Applied Biosystems), and TaqMan PDAR (pre-developed assay reagents) primers/probes. PDAR primers/probes for TNF $\alpha$ (catalogue No 4327055F), IL4 (catalogue No 4327038), and IFN $\gamma$ (catalogue No 4327052) were used. Ribosomal 18S (catalogue No 4310893E) was used as endogenous control. The PCR reactions were run in triplicate wells with $5 \mathrm{ng}$ of each cDNA. The expression of each cytokine was measured also from a home made calibrator sample, which was prepared from PHA stimulated PBMC of a healthy subject.

We used the comparative $\mathrm{Ct}$ method to measure the gene transcription in samples. The Ct of $18 \mathrm{~S}$ was subtracted from the cytokine $\mathrm{Ct}$. This difference was the $\Delta \mathrm{Ct}$ value. The $\Delta \mathrm{Ct}$ of the analysed sample was then subtracted from the $\Delta \mathrm{Ct}$ of the calibrator. This difference is called the $\Delta \Delta \mathrm{Ct}$ value. The results are expressed as relative units based on calculation of $2^{-\Delta \Delta \mathrm{Ct}}$, which gives the relative amount of cytokine normalised to endogenous control (18S) and compared with calibrator.

\section{Statistics}

A comparison of variables between the different follow up samples was carried out with the Wilcoxon signed ranks test. We used the Mann-Whitney test for comparison of two groups. A p value $<0.05$ was considered significant.

\section{RESULTS}

\section{Cytokine and chemokine receptor profile at entry}

At entry, patients with RA and patients with other arthritides showed a lower secretion of IFN $\gamma$ than controls (median 1513 $v 11970 \mathrm{pg} / \mathrm{ml}, \mathrm{p}<0.0001$ and median $3753 v 11970 \mathrm{pg} / \mathrm{ml}$, $\mathrm{p}=0.004$, for patients with RA and other arthritides, respectively; ranges were $0-18700 \mathrm{pg} / \mathrm{ml}$ for $\mathrm{RA}, 0_{-}$ $7370 \mathrm{pg} / \mathrm{ml}$ for other arthritides, $6788-32080 \mathrm{pg} / \mathrm{ml}$ for healthy controls). Also, the ratio of IFN $\gamma /$ IL4 mRNA of PHA stimulated PBMC was lower in RA and in other arthritides than in controls (median $0.2 v 1.7, \mathrm{p}=0.003$ and median $0.0 v$ 1.7, $\mathrm{p}=0.004$, for patients with RA and other arthritides, respectively; ranges $0-13$ for RA, $0-0.3$ for other arthritides, 0-7 for healthy controls). Patients with RA also had a lower number of monocytes expressing CCR3 than controls (median $\mathrm{l} v 2.4, \mathrm{p}=0.009$; ranges $0-5$ for $\mathrm{RA}, \mathrm{l}-7$ for healthy controls). Patients with other arthritides did not differ in the number of monocytes expressing CCR3 (data not shown).

In patients with other arthritides a lower expression of TNF $\alpha$ mRNA was noted than in controls (median $222 v 645$, $p=0.003$; ranges $0-338$ for other arthritides, 270-1701 for healthy controls). Such a difference was not seen between controls and patients with RA (data not shown).

No differences between patient and control groups were seen in the number of T cells expressing CCR3 or CCR5, in the mitogen stimulated secretion of TNF $\alpha$ or IL4, or in the number of monocytes expressing CCR5.

\section{Changes in autoantibodies and serum markers for inflammation during infliximab treatment}

In patients with RA the plasma CRP and SAA levels had decreased by 2 weeks after the first TNF $\alpha$ infusion (median $45 \vee 6 \mu \mathrm{g} / \mathrm{ml}$, range $5-272 \mu \mathrm{g} / \mathrm{ml}$ before treatment and $1-$ $276 \mu \mathrm{g} / \mathrm{ml} 2$ weeks after, $\mathrm{p}<0.0001$ for CRP; and median 236 $v 40 \mathrm{ng} / \mathrm{ml}$, range $14.5-495 \mathrm{ng} / \mathrm{ml}$ before treatment and 4$473 \mathrm{ng} / \mathrm{ml} 2$ weeks after, $\mathrm{p}<0.0001$ for SAA) and were still significantly lower after 6 weeks' follow up when compared with the levels measured before treatment (median $45 \vee 7 \mu \mathrm{g}$ / $\mathrm{ml}$, range $5-272 \mu \mathrm{g} / \mathrm{ml}$ before treatment and $1-93 \mu \mathrm{g} / \mathrm{ml}$ 6 weeks after, $\mathrm{p}<0.0001$ for CRP; and median $236 v 30 \mathrm{ng} / \mathrm{ml}$, range $14-495 \mathrm{ng} / \mathrm{ml}$ before treatment and $7-268 \mathrm{ng} / \mathrm{ml}$ 6 weeks after, $\mathrm{p}<0.0001$ for SAA).

In patients with other arthritides the plasma CRP and SAA levels had decreased significantly by 2 weeks after the start of treatment (median $13 \vee 0 \mu \mathrm{g} / \mathrm{ml}$, range $7-92 \mu \mathrm{g} / \mathrm{ml}$ before 
treatment and $0-5 \mu \mathrm{g} / \mathrm{ml} 2$ weeks after, $\mathrm{p}=0.043$ for CRP; and median $243 v 11 \mathrm{ng} / \mathrm{ml}$, range $20-303 \mathrm{ng} / \mathrm{ml}$ before treatment and $7-22 \mathrm{ng} / \mathrm{ml} 2$ weeks after, $\mathrm{p}=0.043$ for SAA). The SAA levels were decreased also at the 6 week follow up point (median $243 v 11 \mathrm{ng} / \mathrm{ml}$, range 20-303 ng/ml before treatment and 9-137 ng/ml 6 weeks after, $\mathrm{p}=0.043$ ).

No such changes were seen in healthy controls (data not shown).

The level of IgM RF in patients with RA had decreased by 2 weeks after the start of treatment (median $157 v 114 \mathrm{IU} / \mathrm{ml}$, range 2.5-437 before treatment and 4-406 2 weeks after, $\mathrm{p}=0.002)$.

The concentrations of IgG class AFA and CCP autoantibodies in the plasma were not affected by the infliximab treatment during 6 weeks' follow up in patients with RA (data not shown).

\section{Cytokine profile during infliximab treatment}

IFN $\gamma$ and IL4 secretion of PBMC, stimulated by PHA, increased in the patients with RA during the 6 week period of treatment (median $1513 \vee 14190 \mathrm{pg} / \mathrm{ml}, \mathrm{p}<0.0001$ for IFN $\gamma$ and median $23 v 42 \mathrm{pg} / \mathrm{ml}, \mathrm{p}=0.044$ for IL4) (figs IA and $\mathrm{B})$.

In patients with RA the IFN $\gamma$ secretion of PBMC had already increased after 2 weeks of treatment (median $1513 \mathrm{v}$ $10780 \mathrm{pg} / \mathrm{ml}, \mathrm{p}=0.001$ ) and increased further between 2 and 6 weeks (median $10780 \vee 14190$ pg/ml, p=0.022) (fig 1A). The IFN $\gamma$ and IL4 secretion of PHA stimulated PBMC increased also in the patients with other arthritides during the first 2 weeks of treatment (median $3753 v$ $4473 \mathrm{pg} / \mathrm{ml}, \mathrm{p}=0.043$ for IFN $\gamma$ and median $27 \vee 54 \mathrm{pg} / \mathrm{ml}$, $\mathrm{p}=0.043$ for IL4).

No differences during the 6 weeks' follow up were seen in the concentration of PHA stimulated IL5 or TNF $\alpha$ secretion by PBMC from patients with infliximab treatment (data not shown). No differences in the PHA stimulated cytokine secretion of PBMC were found in healthy controls in the samples taken 2 weeks apart (data not shown).

The ratio of IFN $\gamma /$ IL4 mRNA in PHA stimulated PBMC increased during treatment in both patient groups. An increase between 0 and 6 weeks was significant in patients with RA (median $0.2 v 1.5$, range $0-13$ before treatment and 0-15 6 weeks after, $\mathrm{p}<0.0001)$ and for patients with other arthritides (median $0.1 \vee 1.0$, range $0-0.3$ before treatment and $1-26$ weeks after, $p=0.043$ ). No changes were seen in the control subjects.

In patients with RA the TNF $\alpha$ mRNA levels increased during treatment, the increase between 2 and 6 weeks being significant (median $260 \vee 752$, range 0-2784 at 2 weeks and range $86-2784$ at 6 weeks, $p=0.009$ ). No changes in the
TNF $\alpha$ mRNA levels were seen in patients with other arthritides or in healthy controls (data not shown).

\section{Chemokine receptor profile during infliximab treatment}

In patients with RA the number of CD4 T cells and CD14 monocytes expressing CCR3 increased during treatment. The number of CD4 T cells expressing CCR 3 increased between 0 and 2 weeks (median $0.4 v 0.8, \mathrm{p}=0.028$ ) and between 0 and 6 weeks (median $0.4 v 0.6, \mathrm{p}=0.013$ ) (fig $2 \mathrm{~A}$ ). The number of CD14 monocytes expressing CCR3 increased between 0 and 6 weeks (median $0.9 v 2.4, \mathrm{p}=0.009$ ) (fig $2 \mathrm{~B}$ ). No changes in the expression of CCR3 on CD8 T cells were seen during the follow up period in patients with RA.

In patients with RA the expression of CCR5 on CD8 T cells increased during the treatment, the increase between 2 and 6 weeks being significant (median $0.13 \vee 0.2, p=0.040$ ) (fig 2C). No changes were seen in the expression of CCR5 on CD4 T cells or monocytes during the follow up period.

In patients with other arthritides no changes in the expression of CCR5 or CCR3 on T cells or monocytes was seen during the follow up period. In healthy controls the expression of CCR5 on monocytes decreased during the 2 week follow up (median $0.7 v 1.0$, range $0-2$ at 0 weeks and range $0-1$ at 2 weeks, $\mathrm{p}=0.017$ ).

\section{Markers associated with responsiveness to the treatment}

The effect of treatment was determined at 2 weeks' follow up before the second infusion of TNF $\alpha$ blocking agent.

The number of CD8 T cells expressing CCR3 was higher before the start of treatment in non-responders than in responders (median $0.3 v 0.1, \mathrm{p}=0.022$ ) (fig 3A).

The number of CD4 T cells expressing CCR3 and CCR5 was higher in patients not responding to treatment than in the responders throughout the follow up period. The difference between non-responders and responders was significant before the start of treatment for CCR5 (median $0.2 \vee 0.1$, $\mathrm{p}=0.013$ ) (fig 3B) and after 6 weeks of treatment for CCR3 and CCR5 (median $1.5 v 0.3, \mathrm{p}=0.020$ and median $0.3 \vee 0.1$, $\mathrm{p}=0.029$, respectively). Also before the start of treatment a similar trend was seen for CCR3 (median $0.5 v 0.3, \mathrm{p}=0.053$ ) (fig 3C).

In patients with RA the number of CD3 T cells increased in patients responding to treatment and such a change was not seen in non-responders. When the change in the number of CD3 $\mathrm{T}$ cells during treatment was compared, the responders and non-responders differed $(\mathrm{p}=0.001)$ (figs $4 \mathrm{~A}$ and $\mathrm{B})$. No significant differences in other immunological measures
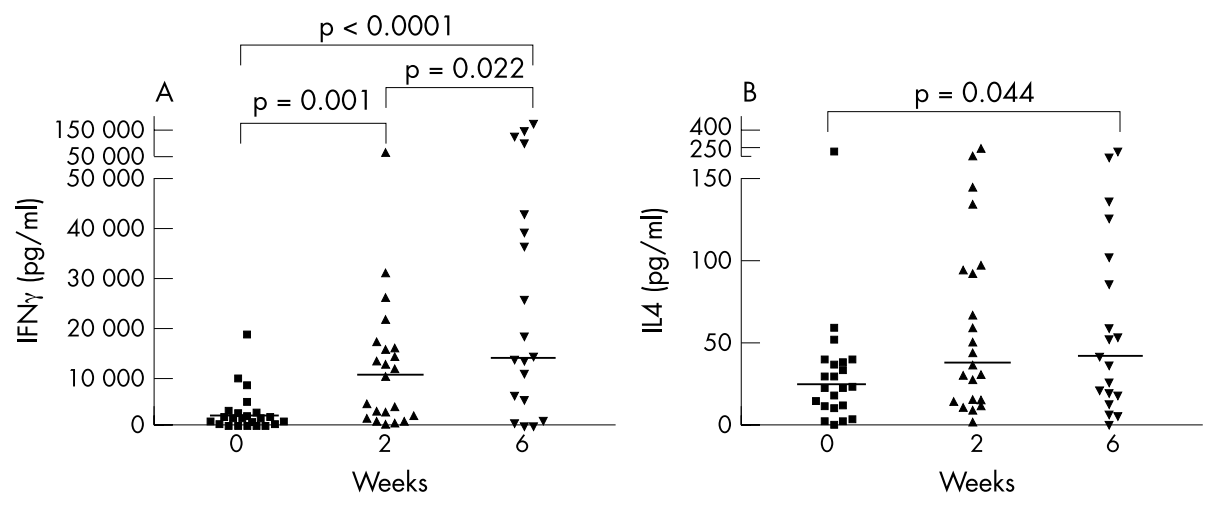

Figure 1 Effect of infliximab on the secretion of IFN $\gamma$ (A) and IL4 (B), studied with an ELISA, from PHA stimulated PBMC in patients with RA. The median values are indicated with horizontal lines. 

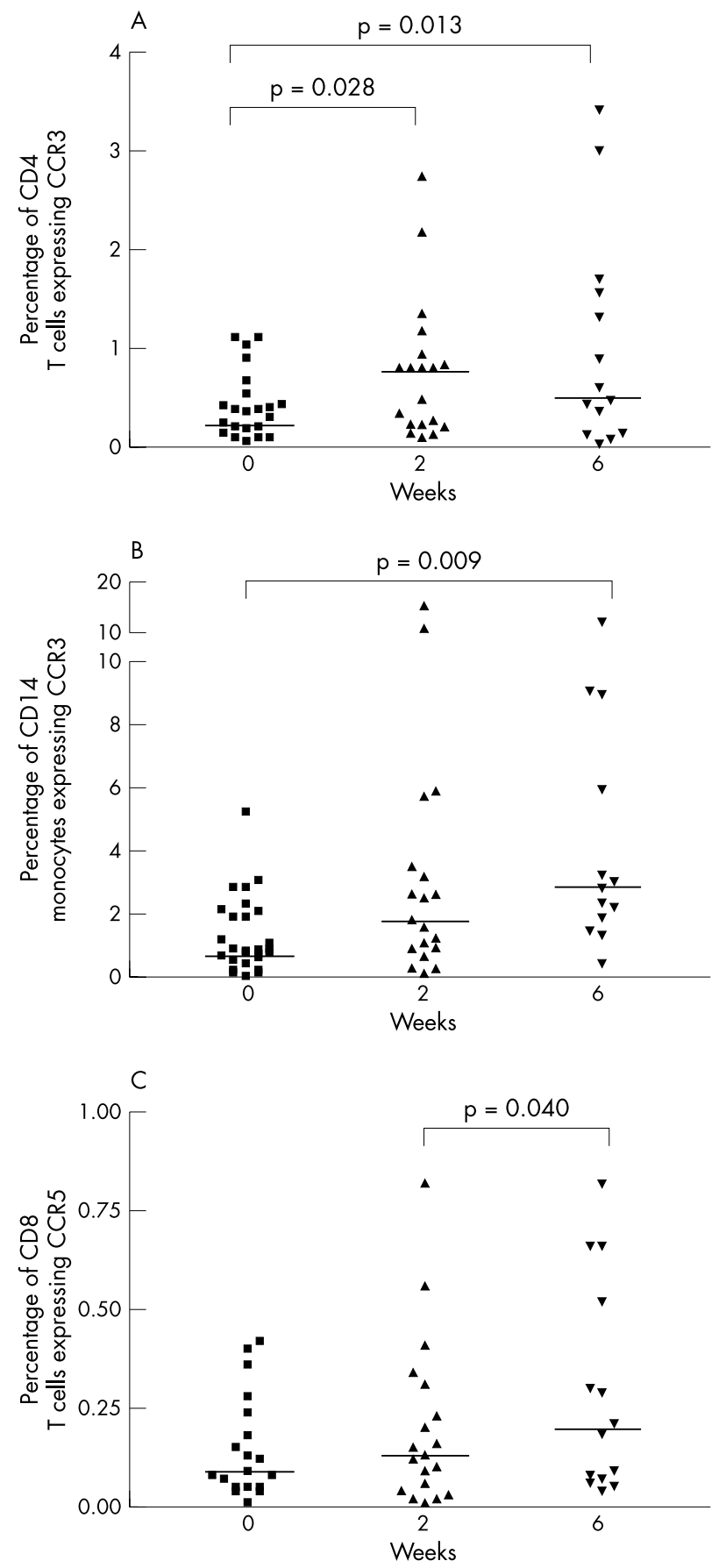

Figure 2 Effect of infliximab treatment on the percentage of (A) CD4 T cells expressing CCR3; (B) CD14 gated monocytes expressing CCR3; and (C) CD8 T cells expressing CCR5 collected from CD3 gate and studied with flow cytometry in patients with RA. The median values are indicated with horizontal lines.

between responders and non-responders were seen (data not shown).

\section{DISCUSSION}

At entry, the patients with RA showed impaired cytokine secretion of PBMC in response to PHA stimulation in comparison with controls, suggesting decreased peripheral $\mathrm{T}$ cell function as reported earlier. ${ }^{16-18}$ The TNF $\alpha$ blockade normalised the mitogen response of PBMC as shown by the normal production of both IFN $\gamma$ and IL4. Activation of type 1

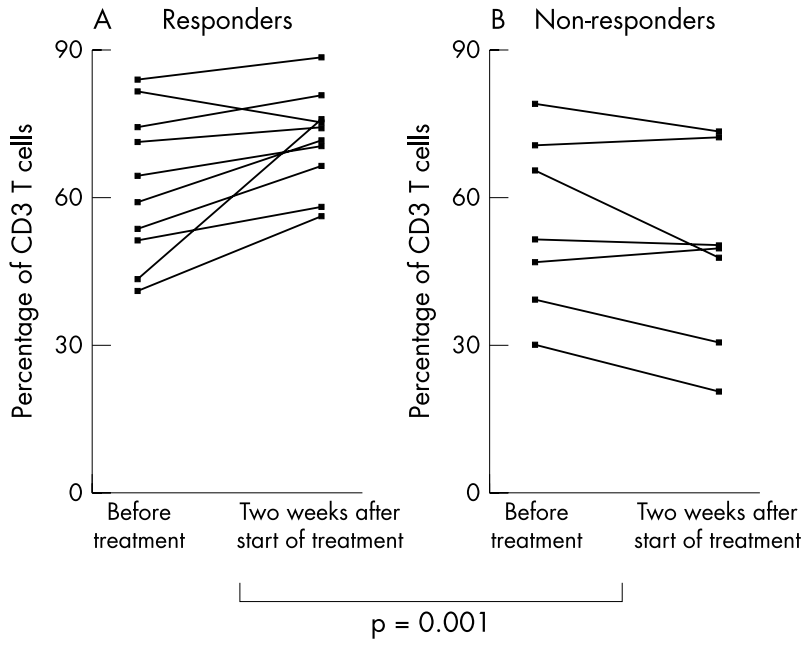

Figure 4 Change in the number of CD3 T cells $(A, B)$ during infliximab treatment studied with flow cytometry in patients with RA responding (A) and not responding $(B)$ to treatment. A comparison of the number of $T$ cells between the groups showed a significant difference $(p=0.001)$. 
immune response, described as an increase in the number of PBMC spontaneously producing IFN $\gamma$ after 4 weeks of treatment with etanercept, a soluble TNF receptor, has been reported earlier by Berg et al. ${ }^{11}$ Also IFN $\gamma$ production of PBMC stimulated with microbial antigens (purified protein derivative, influenza virus) or autoantigen (collagen type II) increased in the patients during treatment. No increase in the mitogen stimulated IFN $\gamma$ production was found, but instead, an increase in the secretion of IL2 was seen. Increased secretion of IL2 and IFN $\gamma$ has also been reported in patients with spondyloarthropathy receiving infliximab. ${ }^{19}$ As a conclusion, these studies together with our study suggest that recovery of impaired Thl response is associated with TNF $\alpha$ blocking. In our study we also found an increase in the type 2 associated cytokine secretion after PHA stimulation in patients receiving infliximab. However, our observation of an increase in the IFN $\gamma /$ IL4 mRNA ratio, stimulated by PHA, suggests a more pronounced effect on type 1 immunity.

It has been reported that the chronic overproduction of TNF $\alpha$ suppresses $\mathrm{T}$ cell functions, ${ }^{20}$ and thus elimination of excess $\mathrm{TNF} \alpha$ in patients receiving $\mathrm{TNF} \alpha$ blocking agent results in recovery of $\mathrm{T}$ cell responses. These findings of enhanced Thl immunity as a response to TNF $\alpha$ blocking challenge the paradigm of pathogenicity of Thl cells in RA, as discussed also in the context of spondyloarthropathy. ${ }^{19}$ Possibly, the recovery of $\mathrm{T}$ cell function is associated with the recovery of regulatory mechanisms, and the impaired peripheral $\mathrm{T}$ cell function may fundamentally be associated with autoimmunity.

We found that the number of $\mathrm{T}$ cells and monocytes expressing CCR3 and CCR5 increased as response to treatment in patients with RA. This indicates activation of peripheral $\mathrm{T}$ cells and is in accordance with the increase in the mitogen stimulated cytokine response observed. It is also possible that the increase in the number of CCR3 and CCR5 expressing cells reflects the decreased accumulation of inflammatory cells from the periphery to inflamed joints, as suggested previously. ${ }^{7}$ In patients with other arthritides we found no change in the expression of chemokine receptors during treatment. This might be due to the small number and heterogeneous disease pattern among the patients studied.

It has been reported that TNF $\alpha$ decreases expression of CCR5 in peripheral blood monocytes and alveolar macrophages by production of the CCR5 ligand, RANTES..$^{21}$ Down regulation of CCR 5 as a response to TNF $\alpha$ is detected also on dendritic cells. ${ }^{22}{ }^{23}$ Hornung et al reported that TNF $\alpha$ affects CCR5 expression on peripheral blood lymphocytes. ${ }^{24}$ They showed that TNF $\alpha$ down regulates the expression of CCR5 on previously activated peripheral blood lymphocytes and delays the expression of CCR5 on the cells early in the activation process. Also, CCR3 is down regulated by TNF $\alpha$ as shown by Sato et al. ${ }^{25}$ Thus, the increase in CCR3 and CCR5 expression on $\mathrm{T}$ cells and monocytes can be explained by a rebound effect due to blocking of TNF $\alpha$.

When patients with RA were divided into responding and non-responding groups according to ACR20 criteria, the patients responding to treatment had a lower numbers of $\mathrm{T}$ cells expressing CCR3 and CCR5 before the start of infusions than the non-responders. High levels of CCR3 and CCR5 on CD4 and on CD8 positive T cells were thus predictive markers of a poor effect of treatment. This suggests that the activation of peripheral $\mathrm{T}$ cells is an important mechanisms in TNF $\alpha$ blocking and, possibly, this treatment is most effective in those patients with impaired peripheral $\mathrm{T}$ cell function, because the excess TNF $\alpha$ also causes down regulation of chemokine receptors. The high levels of CCR3 and CCR5 on the $\mathrm{T}$ cells of patients not responding to infliximab might indicate that in these patients the activity of RA is more dependent on other inflammatory mediators and less on TNF $\alpha$.

It has been reported that patients with RA have a greater number of TNF $\alpha$-producing PBMC both before and after treatment with TNF $\alpha$ blocking agents than healthy controls, and no effect on the number cells spontaneously producing TNF $\alpha$ during TNF $\alpha$ treatment is seen. ${ }^{11}$ In our study treatment increased the expression of TNF $\alpha$ at the mRNA level, probably owing to positive feedback mechanisms, but no effect at the protein level was seen as PHA stimulated secretion of $\mathrm{TNF} \alpha$ did not change during treatment in patients with RA.

Some reports show that the number of circulating lymphocytes is transiently increased after monoclonal antiTNF $\alpha$ antibody treatment in a dose dependent fashion. ${ }^{26}$ In response to treatment, the number of $\mathrm{T}$ cells increased and the CRP levels decreased in the patients who showed good clinical response in our study, but no changes in T cells were seen in the patient group as a whole. Our results suggest that changes in T cell number and CRP are related to the effect of treatment.

In conclusion, the TNF $\alpha$ blocking treatment seems to activate the cell mediated immune system to compensate or to rebalance itself. Increase in the induced production of both type 1 and type 2 cytokines, together with the increase in the number of T cells and monocytes expressing CCR3 and CCR5, suggest that recovery of peripheral $\mathrm{T}$ cell function is associated with the clinical effects of TNF $\alpha$ blocking. This treatment seems to be most effective among those patients with RA who have decreased expression of chemokine receptors on peripheral $\mathrm{T}$ cells before the start of treatment.

\section{ACKNOWLEDGEMENTS}

The authors are indebted to Ms Arja Kaarto for her excellent organising skills and to Ms Anneli Suomela, Mr Harry Lybeck, and Ms Maria Kiikeri for their excellent technical assistance.

This study was supported by grants from the Instrumentarium Research Foundation, Rheumatism Foundation Hospital, Academy of Finland, and the Finnish Cultural Foundation.

\section{Authors' affiliations}

R Nissinen, O Vaarala, Department of Molecular Medicine, National

Public Health Institute, Helsinki, Finland

R Nissinen, T Palosuo, Department of Health and Functional Capacity, National Public Health Institute, Helsinki, Finland

M Leirisalo-Repo, R Peltomaa, Department of Medicine, Division of Rheumatology, Helsinki University Central Hospital, Helsinki, Finland O Vaarala, Division of Paediatrics, Department of Molecular and Clinical Medicine, Linköping University, Linköping, Sweden

\section{REFERENCES}

1 Hale LP, Haynes BF. Pathology of rheumatoid arthritis and associated disorders. In: Koopman WJ, ed. Arthritis and allied conditions. A textbook of rheumatology.13th ed. Baltimore: Williams \& Wilkins, 1997:993-1016.

2 Epstein FH. Cytokine pathways and joint inflammation in rheumatoid arthritis. N Engl J Med 2001;344:907-16.

3 Tracey KJ, Fong Y, Hesse DG, Manogue KR, Lee AT, Kuo GC, et al. Anticachectin/TNF monoclonal antibodies prevent septic shock during lethal bacteraemia. Nature 1987;330:662-4.

4 Feldmann M, Brennan F, Paleolog E, Taylor P, Maini RN. Anti-tumor necrosis factor alpha therapy of rheumatoid arthritis. Mechanism of action. Eur Cytokine Netw 1997;8:297-300.

5 Maini RN, Breedveld FC, Kalden JR, Smolen JS, Davis D, Macfarlane JD, et al. Therapeutic efficacy of multiple intravenous infusions of anti-tumor necrosis factor alpha monoclonal antibody combined with low-dose weekly methotrexate in rheumatoid arthritis. Arthritis Rheum 1998;41:1552-63.

6 Weinblatt ME, Kremer JM, Bankhurst AD, Bulpitt KJ, Fleischmann RM, Fox RI, $\mathrm{J}$ et al. A trial of etanercept, a recombinant tumor necrosis factor receptor:Fc fusion protein, in patients with rheumatoid arthritis receiving methotrexate. N Engl J Med 1999;340:253-9.

7 Paleolog EM, Hunt M, Elliott MJ, Feldmann M, Maini RN, Woody JN. Deactivation of vascular endothelium by monoclonal anti-tumor necrosis factor alpha antibody in rheumatoid arthritis. Arthritis Rheum 1996;39:1082-91.

8 Fong Y, Tracey KJ, Moldawer LL, Hesse DG, Manogue KB, Kenney JS, et al. Antibodies to cachectin/tumor necrosis factor reduce interleukin 1 beta and 
interleukin 6 appearance during lethal bacteremia. J Exp Med 1989; 170:1627-33

9 Charles P, Elliott MJ, Davis D, Potter A, Kalden JR, Antoni C, et al. Regulation of cytokines, cytokine inhibitors, and acute-phase proteins following anti-TNFalpha therapy in rheumatoid arthritis. J Immunol 1999;163:1521-8.

10 Elliott MJ, Maini RN, Feldmann M, Long-Fox A, Charles P, Katsikis P, Brennan FM, et al. Treatment of rheumatoid arthritis with chimeric monoclonal antibodies to tumor necrosis factor alpha. Arthritis Rheum 1993;36:1681-90.

11 Berg L, Lampa J, Rogberg S, van Vollenhoven R, Klareskog L. Increased peripheral T cell reactivity to microbial antigens and collagen type II in rheumatoid arthritis after treatment with soluble TNFalpha receptors. Ann Rheum Dis 2001;60:133-9.

12 Paleolog EM, Young S, Stark AC, McCloskey RV, Feldmann M, Maini RN. Modulation of angiogenic vascular endothelial growth factor by fumor necrosis factor alpha and interleukin-1 in rheumatoid arthritis. Arthritis Rheum 1998;41:1258-65.

13 Felson DT, Anderson JJ, Boers M, Bombardier C, Goldsmith C Furst D, et al. American College of Rheumatology. Preliminary definition of improvement in rheumatoid arthritis. Arthritis Rheum 1995:38:727-35.

14 Palosuo T, Lukka M, Alenius H, Kalkkinen N, Aho K, Kurki P, et al. Purification of filaggrin from human epidermis and measurement of antifilaggrin autoantibodies in sera from patients with rheumatoid arthritis by an enzymelinked immunosorbent assay. Int Arch Allergy Immunol 1998; 15:294-302.

15 Schellekens GA, Visser H, de Jang BAW, van den Hogen FHJ, Hazes JMW, Breedveld FC, et al. The diagnostic properties of rheumatoid arthritis antibodies recognizing a cyclic citrullinated peptide. Arthritis Rheum 2000;43: 155-63.

16 Sadouk M, Vaquero C, de la Tour B, Amor B, Toubert A. Interferon-gamma mRNA expression upon in vitro T lymphocyte activation is decreased in rheumatoid arthritis patients. Clin Immunol Immunopathol 1990;56:37-45.

17 McKenna RM, Wilkins JA, Warrington RJ. Lymphokine production in rheumatoid arthritis and systemic lupus erythematosus. J Rheumatol 1988; 15:1639-42.
18 Seitz M Napierski I, Augustin R, Hunstein W, Kirchner H. Reduced production of interferon alpha and interferon gamma in leukocyte cultures from patients with active rheumatoid arthritis. Scand J Rheumatol 1987;16:257-62.

19 Baeten D, Van Damme N, Van den Bosch F, Kruithof E, De Vos M, Mielants H, et al. Impaired Th1 cytokine production in spondyloarthropathy is restored by anti-TNFalpha. Ann Rheum Dis 2001;60:750-5.

20 Cope AP, Londei M, Chu NR, Cohen SB, Elliott MJ, Brennan FM, et al. Chronic exposure to tumor necrosis factor (TNF) in vitro impairs the activation of T cells through the T cell receptor/CD3 complex; reversal in vivo by anti-TNF antibodies in patients with rheumatoid arthritis. J Clin Invest 1994;94:749-60.

21 Lane BR, Markovitz DM, Woodford NL, Rochford R, Strieter RM, Coffey MJ. TNF-alpha inhibits HIV-1 replication in peripheral blood monocytes and alveolar macrophages by inducing the production of RANTES and decreasing C-C chemokine receptor 5 (CCR5) expression. J Immunol 1999; 163:3653-61

22 Sallusto F, Lanzavecchia A, Mackay CR. Chemokines and chemokine receptors in T-cell priming and Th1/Th2-mediated responses. Immunol Today 1998;19:568-74.

23 Sallusto F, Palermo B, Lenig D, Miettinen M, Matikainen S, Julkunen I, et al. Distinct patterns and kinetics of chemokine production regulate dendritic cell function. Eur J Immunol 1999;29:1617-25.

24 Hornung F, Scala G, Lenardo MJ. TNF-alpha-induced secretion of C-C chemokines modulates $\mathrm{C}-\mathrm{C}$ chemokine receptor 5 expression on peripheral blood lymphocytes. J Immunol 2000; 164:6180-7.

25 Sato K, Kawasaki H, Nagayama H, Enomoto M, Morimoto C, Tadokoro K, et al. TGF-beta 1 reciprocally controls chemotaxis of human peripheral blood monocyte-derived dendritic cells via chemokine receptors. J Immunol 2000; 164:2285-95

26 Lorenz HM, Antoni C, Valerius T, Repp R, Grunke M, Schwerdtner N, et al. In vivo blockade of TNF-alpha by intravenous infusion of a chimeric monoclonal TNF-alpha antibody in patients with rheumatoid arthritis. Short term cellular and molecular effects. J Immunol 1996;156:1646-53. 